\title{
Evaluation of the Inhibition of Carbohydrate Hydrolyzing Enzymes, the Antioxidant Activity, and the Polyphenolic Content of Citrus limetta Peel Extract
}

\author{
Eduardo Padilla-Camberos, ${ }^{1}$ Estefania Lazcano-Díaz, ${ }^{1}$ José Miguel Flores-Fernandez, ${ }^{1}$ \\ Moses S. Owolabi, ${ }^{2}$ Kirk Allen, ${ }^{3}$ and Socorro Villanueva-Rodríguez ${ }^{1}$ \\ ${ }^{1}$ Centro de Investigación y Asistencia en Tecnología y Diseño del Estado de Jalisco, A.C., Avenida Normalistas 800, \\ Colinas de la Normal, 44270 Guadalajara, JAL, Mexico \\ ${ }^{2}$ Department of Chemistry, Lagos State University, PMB 0001, Lasu Post Office, Ojo, Lagos, Nigeria \\ ${ }^{3}$ Lancaster Medical School, Lancaster University, Lancaster LA1 4YG, UK
}

Correspondence should be addressed to Eduardo Padilla-Camberos; epadilla@ciatej.mx

Received 1 August 2014; Revised 25 November 2014; Accepted 28 November 2014; Published 21 December 2014

Academic Editor: Walter Hunziker

Copyright (C) 2014 Eduardo Padilla-Camberos et al. This is an open access article distributed under the Creative Commons Attribution License, which permits unrestricted use, distribution, and reproduction in any medium, provided the original work is properly cited.

\begin{abstract}
Type 2 diabetes mellitus is one of the most frequent causes of death in Mexico, characterized by chronic hyperglycemia. One alternative strategy for this metabolic abnormality is inhibiting the enzymes responsible for the metabolism of carbohydrates. We evaluated whether the aqueous Citrus limetta peel extract could inhibit the metabolism of carbohydrates. We found that this extract inhibited primarily the enzyme $\alpha$-amylase by $49.6 \%$ at a concentration of $20 \mathrm{mg} / \mathrm{mL}$ and to a lesser extent the enzyme $\alpha$ glucosidase with an inhibition of $28.2 \%$ at the same concentration. This inhibition is likely due to the high polyphenol content in the Citrus limetta peel (19.1 mg GAE/g). Antioxidant activity of the Citrus limetta peel demonstrated dose-dependent antioxidant activity, varying from $6.5 \%$ at $1.125 \mathrm{mg} / \mathrm{mL}$ to $42.5 \%$ at $20 \mathrm{mg} / \mathrm{mL}$. The study of these polyphenolic compounds having both antihyperglycemic and antioxidant activities may provide a new approach to the management of type 2 diabetes mellitus.
\end{abstract}

\section{Introduction}

Diabetes mellitus (DM) is a metabolic disorder, characterized by hyperglycemia and by disturbances in the metabolism of fat and protein, resulting from defects in insulin secretion and/or insulin action [1]. Type $2 \mathrm{DM}$ or noninsulin dependent $\mathrm{DM}$ is the most frequent form with $90-95 \%$ of $\mathrm{DM}$ cases [2]. Currently, Mexico ranks ninth in prevalence of type 2 DM $[3,4]$. Several studies have been conducted to elucidate the possible biochemical mechanisms involved in the pathogenesis of type $2 \mathrm{DM}$, but the exact mechanism is still unclear. Hyperglycemia, one of the main characteristics of type $2 \mathrm{DM}$, is considered the main cause of complications from diabetes [5]. Several pharmacological approaches have been used to improve diabetes treatment through different modes of action including stimulating insulin release, inhibiting gluconeogenesis, increasing the number of glucose transporters, and reducing glucose absorption from the intestine [2], which is achieved with enzyme inhibitors such as acarbose, voglibose, and miglitol [6]. Gastrointestinal side effects make pharmacological approaches less attractive as therapeutic agents, which makes natural remedies viable alternatives [7]. Previous studies have shown that the ability to inhibit enzymes is responsible for carbohydrate metabolism by different natural compounds [5]. Over 200 pure bioactive compounds isolated from plants have shown the effect of reducing blood glucose [8], several of which are polyphenolic compounds [9]. Citrus limetta, commonly known as sweet lime, is an edible fruit from Central America [10]. It is small, with oval and spherical shape, with a greenish yellow peel, rich in polyphenols, flavonoids, flavanones, and flavones [11]. This fruit is typically used for human 
consumption, and it has also been used for cholesterol control and inflammation regulation as well as digestive disorders and as a modulator of blood pressure [12]. Citrus limetta is comprised of $8-10 \%$ peel, which generally is a byproduct without any use, becoming an environmental problem [13]. Recent studies have shown interest in the possible beneficial effects of foods rich in polyphenols [14], which have different activities, among the most interesting of which are carbohydrate metabolism by inhibiting the $\alpha$-glucosidase and $\alpha$-amylase enzymes responsible for carbohydrate digestion [15], avoiding the chronic hyperglycemia symptoms that characterize type 2 DM.

\section{Materials and Methods}

2.1. Plant Material. Citrus limetta was purchased in Jalisco, Mexico. The peel was dried at $37^{\circ} \mathrm{C}$, then ground and sieved $(300 \mu \mathrm{m})$, and packaged until use. Citrus limetta peel extract $0.5 \mathrm{~g}$ sample was homogenized in $25 \mathrm{~mL}$ of distilled water and then filtered on Whatman 40 to remove particles. The obtained sample was placed in an amber bottle and kept at $4^{\circ} \mathrm{C}$ until use.

2.2. Total Polyphenolic Assay. Total phenolic content was determined using Folin-Ciocalteu method [16]. $15 \mu \mathrm{L}$ of extract sample at different concentrations $(20,10,5,2.5$, and $1.125 \mathrm{mg} / \mathrm{mL}$ ) was mixed with $750 \mu \mathrm{L}$ of $0.2 \mathrm{M}$ FolinCiocalteu reagent and $600 \mu \mathrm{L}$ of $7.5 \%$ sodium carbonate. The absorbance was measured at $765 \mathrm{~nm}$ after incubation in the dark for 2 hours. Gallic acid was used as standard. The total polyphenol content was expressed as milligrams of gallic acid equivalents (GAE) per gram of sample.

2.3. Antioxidant Activity. Antioxidant activity was evaluated by the 2,2-diphenyl-2-picrylhydrazyl (DPPH) method [17]. $20 \mu \mathrm{L}$ of the extract was mixed at different concentrations $(20,10,5,2.5$, and $1.125 \mathrm{mg} / \mathrm{mL})$, with $200 \mu \mathrm{L}$ of $36 \mu \mathrm{M} \mathrm{DPPH}$ in $80 \%$ methanol and then was incubated in the dark for $30 \mathrm{~min}$. The absorbance was measured at $515 \mathrm{~nm}$. Ascorbic acid at $300 \mu \mathrm{g} / \mathrm{mL}$ was used as standard. The total antioxidant activity (\%TAA) was expressed as the percentage inhibition of $\mathrm{DPPH}$ radical and determined with the following equation:

$$
\% \mathrm{TAA}=\frac{\text { Abs control }- \text { Abs sample }}{\text { Abs control }} \times 100
$$

where \%TAA is antioxidant activity and Abs is absorbance.

2.4. $\alpha$-Glucosidase Inhibition Essay. Inhibition of $\alpha$-glucosidase enzyme was determined colorimetrically by monitoring the release of 4-nitrophenol from 4-nitrophenyl- $\alpha$-Dglucopyranoside (pNPG) [18]. $50 \mu \mathrm{L}$ of extract at different concentrations $(20,10,5,2.5$, and $1.125 \mathrm{mg} / \mathrm{mL})$ was preincubated with $100 \mu \mathrm{L}$ of $\alpha$-glucosidase enzyme ( $1 \mathrm{U} / \mathrm{mL}$ ) (Sigma Aldrich). The reaction was carried out by adding $50 \mu \mathrm{L}$ pNPG followed by 30 minutes incubation at $25^{\circ} \mathrm{C}$. Acarbose was used as standard. Phosphate buffer was used as blank.
The inhibition percentage was determined with the following equation:

\%Inhibition $=100 \times \frac{\left(\operatorname{Abs} C_{x}-\operatorname{Abs} C_{o}\right)-\left(\operatorname{Abs} M_{x}-\operatorname{Abs} M_{o}\right)}{\left(\operatorname{Abs} C_{x}-\operatorname{Abs} C_{o}\right)}$,

where $A b s C_{x}$ is absorbance of control at minute $5, \operatorname{Abs} C_{o}$ is absorbance of control at minute $0, \mathrm{Abs} M_{x}$ is absorbance of sample at minute 5 , and $\mathrm{Abs} M_{o}$ is absorbance of sample at minute 0 .

2.5. $\alpha$-Amylase Inhibition Essay. $250 \mu \mathrm{L}$ of sample at different concentrations $20,10,5,2.5$, and $1.125 \mathrm{mg} / \mathrm{mL}$ was preincubated with $250 \mu \mathrm{L}$ of $\alpha$-amylase enzyme ( $2 \mathrm{U} / \mathrm{mL}$ ) (Sigma Aldrich); then $250 \mu \mathrm{L}$ of $1 \%$ starch was added and the sample was incubated at $25^{\circ} \mathrm{C}$ for 10 minutes. The reaction was stopped by adding $500 \mu \mathrm{L}$ 3,5-Dinitrosalicylic acid (DNS). The sample was immediately incubated in a water bath at $95^{\circ} \mathrm{C}$ for 5 minutes and then was cooled to room temperature and $5 \mathrm{~mL}$ of distilled water was added. Acarbose was used as standard and phosphate buffer as blank. The absorbance was measured at $540 \mathrm{~nm}$. The inhibition percentage was determined with the following equation:

$$
\% \mathrm{TAA}=\frac{\text { Abs control }- \text { Abs sample }}{\text { Abs control }} \times 100,
$$

where Abs is the absorbance.

2.6. Statistical Analysis. All experiments were executed in triplicate and the data were expressed as mean \pm standard deviation. Statistical comparisons were performed by oneway analysis of variance followed by Least Significant Difference $(P<0.05)$ using Statgraphics XVI software.

\section{Results}

3.1. Total Polyphenolic Content. The Citrus limetta extract showed a total phenolic content of $19.1 \pm 1.6 \mathrm{mg} \mathrm{GAE} / \mathrm{g}$ in a sample concentration $20 \mathrm{mg} / \mathrm{mL}$.

3.2. Antioxidant Activity. The Citrus limetta extract showed high antioxidant activity and was dose-dependent (Figure 1). The activity was $42.5,29.1,18.6,8.1$, and $6.5 \%$ at concentrations of $20,10,5,2.5$, and $1.125 \mathrm{mg} / \mathrm{mL}$, respectively (Figure 1).

3.3. $\alpha$-Glucosidase Inhibition. The enzymatic activity of $\alpha$ glucosidase was inhibited by all concentrations of the Citrus limetta peel extract. The inhibition was in a dose-dependent manner. The activity was $28.2,21.0,16.6,14.5$, and $5.2 \%$ at concentrations of $20,10,5,2.5$, and $1.125 \mathrm{mg} / \mathrm{mL}$, respectively (Figure 2).

3.4. $\alpha$-Amylase Inhibition. The enzymatic activity of $\alpha$ amylase was inhibited by the Citrus limetta extract by 49.6 , $45.3,42.8,40.6$, and $40.1 \%$ at concentrations of $20,10,5,2.5$, and 1.125 , respectively (Figure 3 ). 


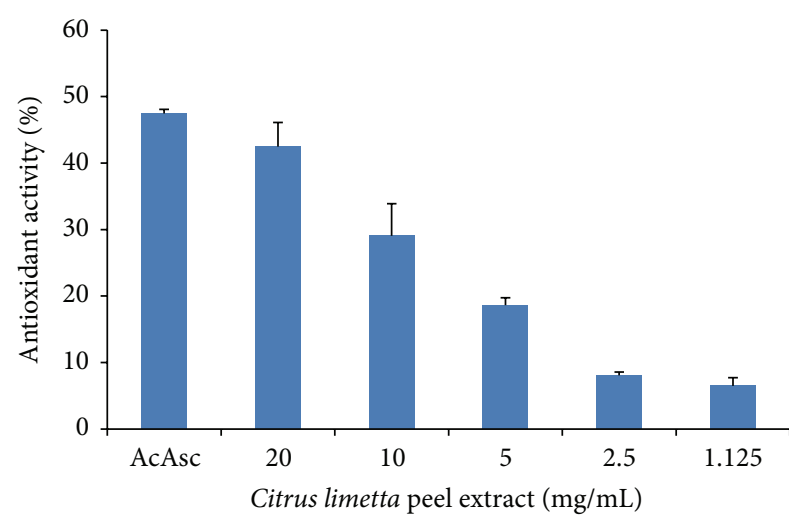

Figure 1: Antioxidant activity at different concentrations of Citrus limetta peel extract. Data mean \pm S.D. are plotted $(n=3)$. Ascorbic acid (AcAsc) at $300 \mu \mathrm{g} / \mathrm{mL}$ was used as standard.

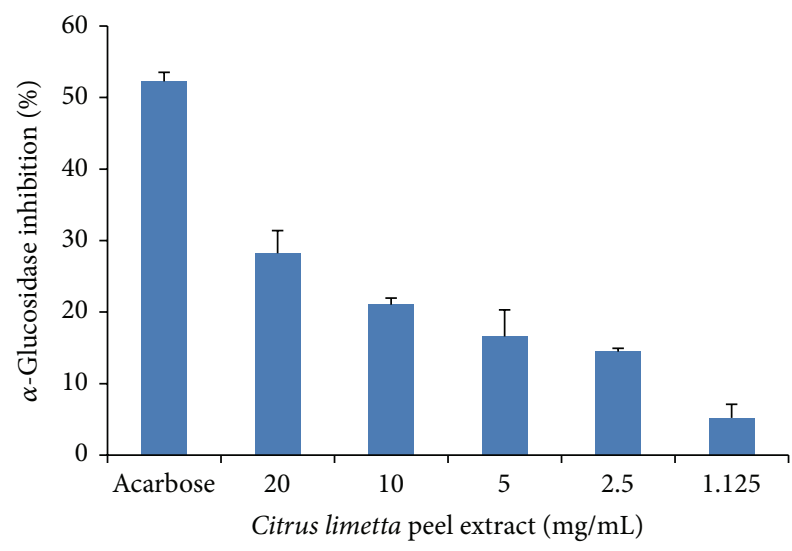

FIGURE 2: $\alpha$-Glucosidase inhibition at different concentrations of Citrus limetta peel extract. Data mean \pm S.D. are plotted $(n=3)$. Acarbose was used as standard.

\section{Discussion}

Hyperglycemia is a metabolic abnormality common in the people with type $2 \mathrm{DM}$. Hyperglycemia is characterized by increased levels of glucose in the blood; thus it is essential to maintain the glucose levels close to normal [19]. The enzyme $\alpha$-amylase is an endoglucanase that hydrolyzes polysaccharides, and $\alpha$-glucosidase is located in the membrane of the surface of the edge in brush of intestinal cells [20,21]. These enzymes are key for digestion and carbohydrates absorption, thus regulating the glucose levels in blood [2].

In this study, we evaluated the ability of Citrus limetta peel extract to inhibit the enzymatic activity of $\alpha$-glucosidase and $\alpha$-amylase and observed a positive correlation between the total content of polyphenols and enzymatic activity. The dose-dependent relationships suggest that polyphenols of the Citrus limetta extract are partly responsible for the inhibition of the enzymatic activity.

Some studies have shown the power with which polyphenols inhibit activities of $\alpha$-glucosidase and $\alpha$-amylase [22, 23]. Flavonoids weakly inhibit $\alpha$-glucosidase, though they are

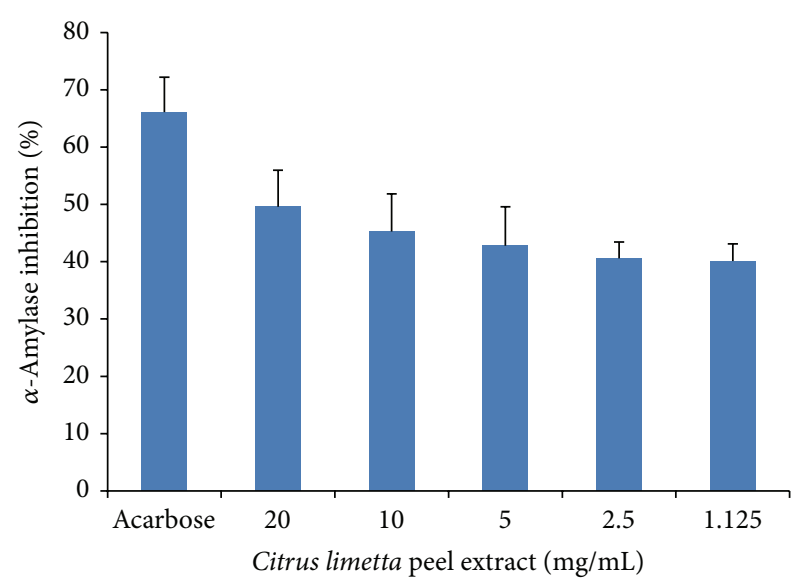

Figure 3: $\alpha$-Amylase inhibition at different concentrations of Citrus limetta peel extract. Data mean \pm S.D. are plotted $(n=3)$.

often potent inhibitors of $\alpha$-amylase [22]. This coincides with our obtained results because Citrus limetta peel extract was a weak inhibitor of $\alpha$-glucosidase activity but a potent inhibitor of the enzymatic activity of $\alpha$-amylase. This difference could be due to different polyphenols present in the extract.

The polyphenolic compounds may also be indirectly beneficial to DM by the chelating metallic ions [24] or by activating the antioxidant enzyme expression [25]. A high total content of polyphenols is not always translated to a high antioxidant activity. The antioxidant activity appears depending on the position and degree of hydroxylation and conjugation [26].

It has been found that peels are the main sources of polyphenols from fruits [27], since these participate in purification of free radicals and may be involved in the inhibition of enzymatic activity [16].

According to the results obtained at different concentrations, we observed that the antioxidant and inhibitory activity of the enzymes which hydrolyze carbohydrates depends on the concentration of polyphenols present in the Citrus limetta peel extract.

\section{Conclusion}

The aqueous extract of Citrus limetta peel showed a potent inhibition of the enzymatic activity of $\alpha$-glucosidase and $\alpha$ amylase, which could be related to the polyphenol content. However, further studies are required using polyphenolic isolated compounds, as well as studies in vivo. The results give the possibility that the peel of Citrus limetta, which is generally discarded, becoming an ecological problem, could be exploited for use as an alternative for the control of hyperglycemia in people with type $2 \mathrm{DM}$.

\section{Conflict of Interests}

The authors declare that they do not have any conflict of interests. 


\section{References}

[1] C. C. Teixeira, C. A. Rava, P. Mallman da Silva et al., "Absence of antihyperglycemic effect of jambolan in experimental and clinical models," Journal of Ethnopharmacology, vol. 71, no. 1-2, pp. 343-347, 2000.

[2] O. O. Olaokun, L. J. McGaw, J. N. Eloff, and V. Naidoo, "Evaluation of the inhibition of carbohydrate hydrolysing enzymes, antioxidant activity and polyphenolic content of extracts of ten African Ficus species (Moraceae) used traditionally to treat diabetes," BMC Complementary and Alternative Medicine, vol. 13, article 94, 2013.

[3] S. Wild, G. Roglic, A. Verde, R. Sicree, and H. el Rey, "La prevalencia global de la diabetes: las estimaciones para el año 2000 y las proyecciones para 2030," Diabetes Care, vol. 27, pp. 10471053, 2000.

[4] A. Arredondo and E. de Icaza, "Costos de la diabetes en Amerŕica Latina: evidencias del Caso Mexicano," Value in Health, vol. 14, no. 5, supplement, pp. S85-S88, 2011.

[5] C. M. Picot, A. H. Subratty, and M. F. Mahomoodally, "Inhibitory potential of five traditionally used native antidiabetic medicinal plants on $\alpha$-amylase, $\alpha$-glucosidase, glucose entrapment, and amylolysis kinetics in vitro," Advances in Pharmacological Sciences, vol. 2014, Article ID 739834, 7 pages, 2014.

[6] J.-Y. Youn, H.-Y. Park, and K.-H. Cho, "Anti-hyperglycemic activity of Commelina communis L.: inhibition of $\alpha$-glucosidase," Diabetes Research and Clinical Practice, vol. 66, pp. S149S155, 2004.

[7] Y.-M. Kim, Y.-K. Jeong, M.-H. Wang, W.-Y. Lee, and H.-I. Rhee, "Inhibitory effect of pine extract on $\alpha$-glucosidase activity and postprandial hyperglycemia," Nutrition, vol. 21, no. 6, pp. 756761, 2005.

[8] R. A. DeFronzo, "Pharmacologic therapy for type 2 diabetes mellitus," Annals of Internal Medicine, vol. 131, no. 4, pp. 281303, 1999.

[9] R. Habasa-Lhoret and J. L. Chiasson, " $\alpha$-glucosidase inhibitors," in International Textbook of Diabetes Mellitus, R. A. Defronzo, E. Ferrannini, H. Keen, and P. Zimmet, Eds., vol. 1, pp. 901-914, John Wiley \& Sons, London, UK, 3rd edition, 2004.

[10] Servicio de Información Agroalimentaria y Pesquera (SIAP), Producción Agrícolaporestado, Cíclicosy Perennes, Modalidad: Riego + Temporal, SIAP México, 2012.

[11] G.-N. Kim, J.-G. Shin, and H.-D. Jang, "Antioxidant and antidiabetic activity of Dangyuja (Citrus grandis Osbeck) extract treated with Aspergillus saitoi," Food Chemistry, vol. 117, no. 1, pp. 35-41, 2009.

[12] S. Kundusen, P. Saha, S. Bhattacharya et al., "Evaluation of in vitro antioxidant activity of Citrus limetta and Citrus maxima on reactive oxygen and nitrogen species," Pharmacologyonline, vol. 3, pp. 850-857, 2010.

[13] J. Fernández-López, J. M. Fernández-Ginés, L. AlesonCarbonell, E. Sendra, E. Sayas-Barberá, and J. A. Pérez-Alvarez, "Application of functional citrus by-products to meat products," Trends in Food Science and Technology, vol. 15, no. 3-4, pp. 176-185, 2004.

[14] A. Scalbert and G. Williamson, "Dietary intake and bioavailability of polyphenols," Journal of Nutrition, vol. 130, no. 8, pp. 2073S-2085S, 2000.

[15] K. Johnston, P. Sharp, M. Clifford, and L. Morgan, "Dietary polyphenols decrease glucose uptake by human intestinal Caco2 cells," FEBS Letters, vol. 579, no. 7, pp. 1653-1657, 2005.
[16] Ş. Gözlekçi, O. Saraçoǧlu, E. Onursal, and M. Özgen, “Total phenolic distribution of juice, peel, and seed extracts of four pomegranate cultivars," Pharmacognosy Magazine, vol. 7, no. 26, pp. 161-164, 2011.

[17] T. Kuljarachanan, S. Devahastin, and N. Chiewchan, "Evolution of antioxidant compounds in lime residues during drying," Food Chemistry, vol. 113, no. 4, pp. 944-949, 2009.

[18] M. I. Kazeem, J. V. Ogunbiyi, and A. O. T. Ashafa, "In vitro studies on the inhibition of $\alpha$-amylase and $\alpha$-glucosidase by leaf extracts of Picralima nitida (Stapf)," Tropical Journal of Pharmaceutical Research, vol. 12, no. 5, pp. 719-725, 2013.

[19] A. K. Tiwari and J. M. Rao, "Diabetes mellitus and multiple therapeutic approaches of phytochemicals: present status and future prospects," Current Science, vol. 83, no. 1, pp. 30-38, 2002.

[20] W. Hunziker, M. Spiess, G. Semenza, and H. F. Lodish, "The sucrase-isomaltase complex: primary structure, membraneorientation, and evolution of a stalked, intrinsic brush border protein," Cell, vol. 46, no. 2, pp. 227-234, 1986.

[21] A. Bougatef, M. Hajji, R. Balti, I. Lassoued, Y. Triki-Ellouz, and M. Nasri, "Antioxidant and free radical-scavenging activities of smooth hound (Mustelus mustelus) muscle protein hydrolysates obtained by gastrointestinal proteases," Food Chemistry, vol. 114, no. 4, pp. 1198-1205, 2009.

[22] G. J. McDougall, F. Shpiro, P. Dobson, P. Smith, A. Blake, and D. Stewart, "Different polyphenolic components of soft fruits inhibit $\alpha$-amylase and $\alpha$-glycosidase," Journal of Agricultural and Food Chemistry, vol. 53, no. 7, pp. 2760-2766, 2005.

[23] K. Tadera, Y. Minami, K. Takamatsu, and T. Matsuoka, "Inhibition of $\alpha$-glucosidase and $\alpha$-amylase by flavonoids," Journal of Nutritional Science and Vitaminology, vol. 52, no. 2, pp. 149-153, 2006.

[24] J. E. Brown, H. Khodr, R. C. Hider, and C. A. Rice-Evans, "Structural dependence of flavonoid interactions with $\mathrm{Cu}^{2+}$ ions: implications for their antioxidant properties," Biochemical Journal, vol. 330, no. 3, pp. 1173-1178, 1998.

[25] C. A. Rice-Evans, N. J. Miller, and G. Paganga, "Structureantioxidant activity relationships of flavonoids and phenolic acids," Free Radical Biology \& Medicine, vol. 20, no. 7, pp. 933956, 1996.

[26] R. Pulido, L. Bravo, and F. Saura-Calixto, "Antioxidant activity of dietary polyphenols as determined by a modified ferric reducing/antioxidant power assay," Journal of Agricultural and Food Chemistry, vol. 48, no. 8, pp. 3396-3402, 2000.

[27] A. Jiménez-Escrig, M. Rincón, R. Pulido, and F. Saura-Calixto, "Guava fruit (Psidium guajava L.) as a new source of antioxidant dietary fiber," Journal of Agricultural and Food Chemistry, vol. 49, no. 11, pp. 5489-5493, 2001. 


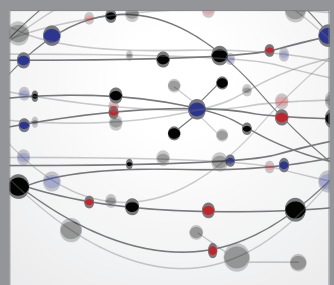

The Scientific World Journal
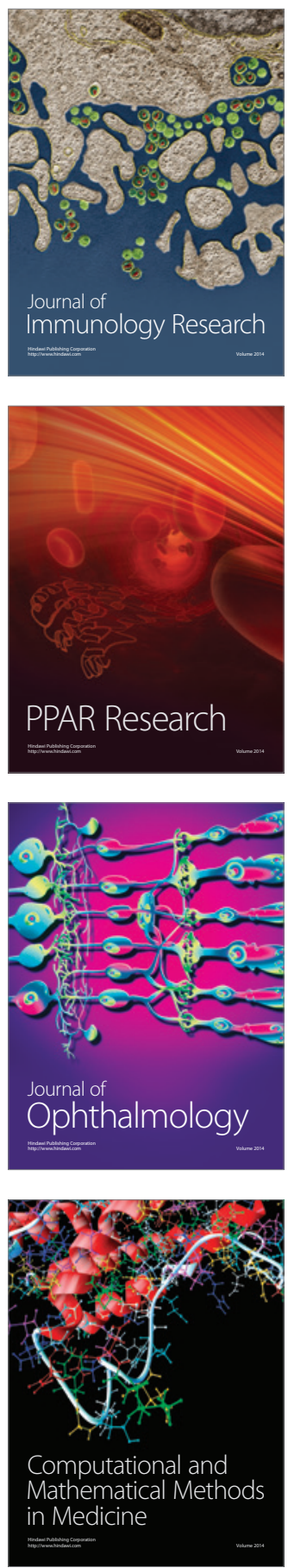

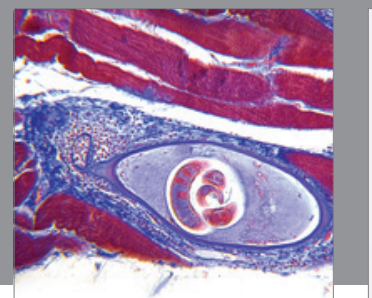

Gastroenterology

Research and Practice
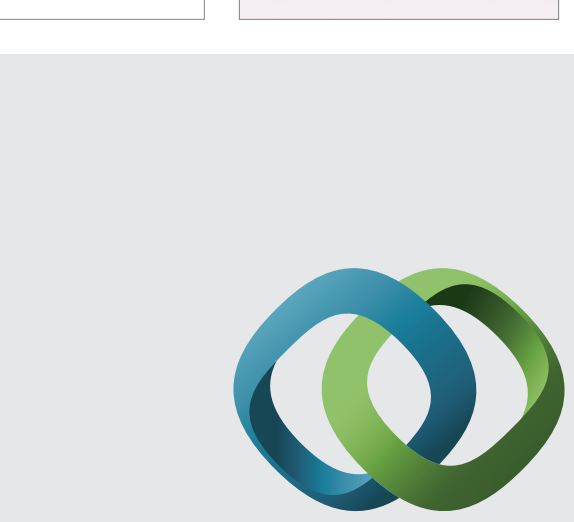

\section{Hindawi}

Submit your manuscripts at

http://www.hindawi.com
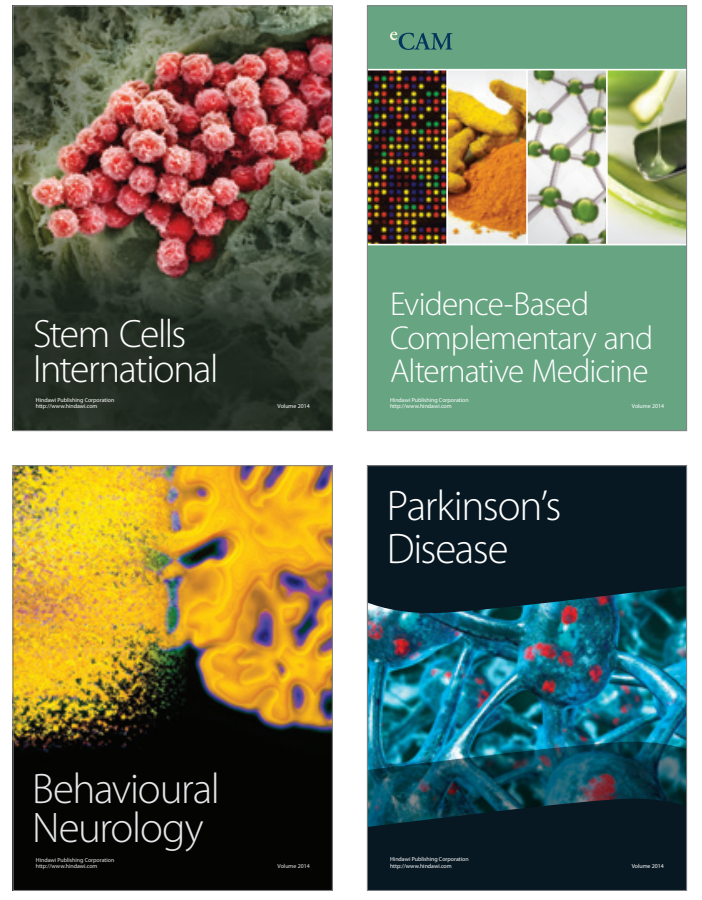
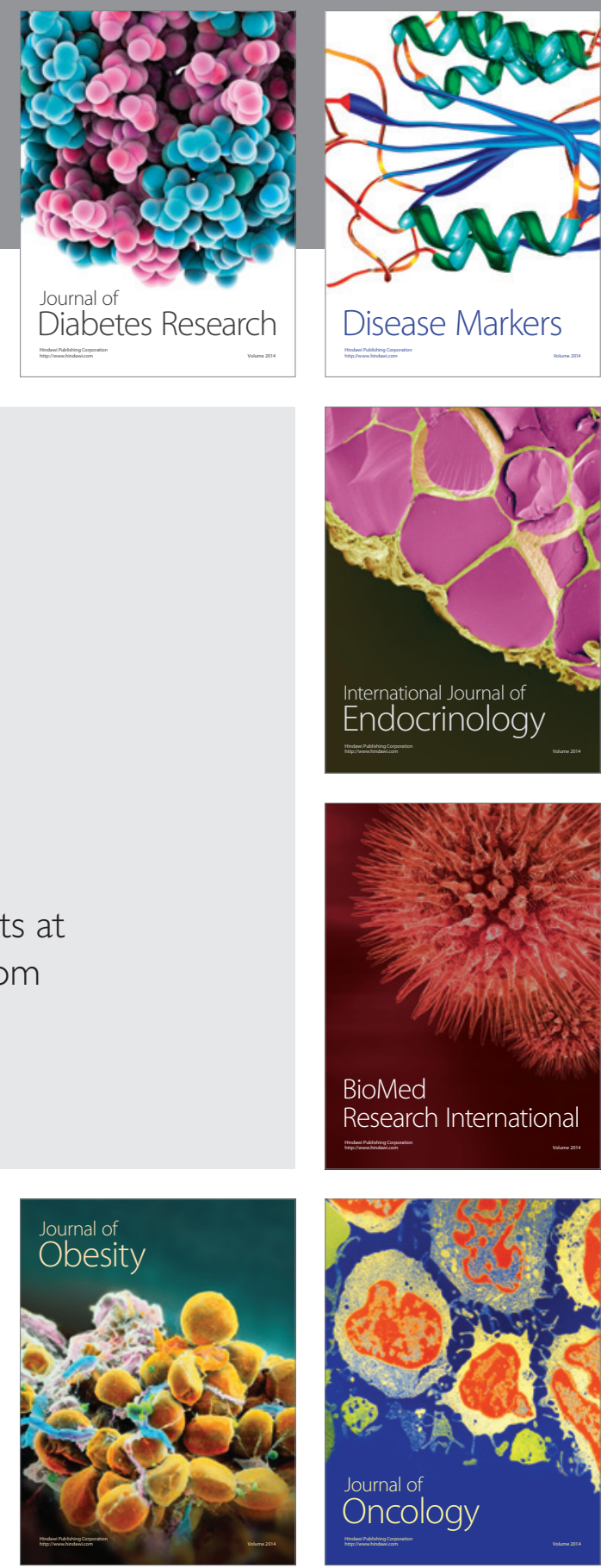

Disease Markers
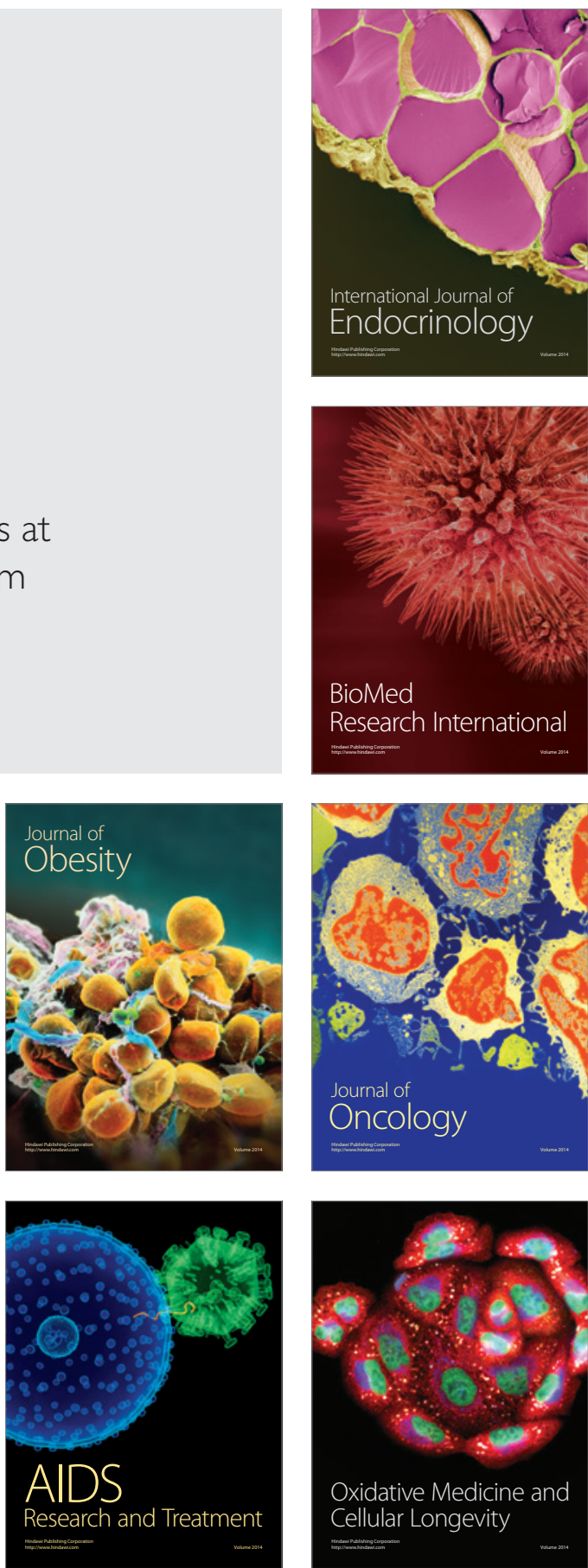